\title{
Natural history clues to the evolution of bivalved gastropods (Mollusca: Gastropoda: Sacoglossa: Juliidae)
}

\author{
Nur Leena W. S. Wong ${ }^{1,2} \cdot$ Julia D. Sigwart ${ }^{3}$ (I)
}

Received: 14 September 2018 / Revised: 10 April 2019 / Accepted: 15 April 2019 / Published online: 23 May 2019

(C) The Author(s) 2019

\begin{abstract}
Bivalved gastropods (family Juliidae) are a pan-tropical group of small, green, extraordinary gastropods with a symmetrical clam-like shell. Only a single species of Juliidae has been reported in Malaysia, Berthelinia singaporensis Jensen, 2015, feeding on multiple species of siphonous green algae in the genus Caulerpa. In spite of a baseline expectation for megadiversity in this region, including 13 recorded species in the genus Caulerpa from two small field sites studied here, B. singaporensis appears to be a relative generalist without preferences among available Caulerpa spp. that occur in suitable (micro)habitats. The life cycle of Juliidae includes univalve, coiled larvae that transform to bivalved adults. In the presence of Caulerpa, swimming veligers rapidly settle and begin feeding; in a later, terminal metamorphosis, the larval operculum is shed, and the teleoconch shell field splits to form a second, right valve of the adult bivalved form. By three days after hatching, settled larvae achieve a fully functional bivalved shell with a working hinge. Both veligers and adults produce an unusual elastic mucous tether to maintain attachment to the substratum or food plant. These animals are dependent on Caulerpa for their entire life cycle; so, adults occupy environments where dislodgement may be a substantial risk. In the adult, bivalved, form, the gastropod can withdraw completely into its shell and close the valves while maintaining the byssus-like tether. This arrangement, enabling the gastropod to be simultaneously anchored to the food plant and protected within the shell, suggests that being able to use a byssus is the most plausible adaptive explanation for the evolution of the bivalved form within gastropods.
\end{abstract}

Keywords tropical biodiversity $\cdot$ molluscan evolution $\cdot$ adaptation

\section{Introduction}

Over and above the basic principle that there are more species in the tropics, the highest density and diversity of species in shallow marine habitats occur in Southeast Asia (e.g. Edie et al. 2018). This region presents a quandary that is familiar to all who work on its fauna: On the one hand, the biodiversity of SE Asia is globally important in terms of both its

Communicated by V. Urgorri

Julia D. Sigwart

j.sigwart@qub.ac.uk

1 Department of Aquaculture, Faculty of Agriculture, Universiti Putra Malaysia, 43400 UPM Serdang, Selangor, Malaysia

2 International Institute of Aquaculture and Aquatic Sciences, Universiti Putra Malaysia, Teluk Kemang, Port Dickson, Negeri Sembilan, Malaysia

3 Marine Laboratory, Queen's University Belfast, 12-13 The Strand, Portaferry, N. Ireland, UK contributions to total world species richness and its pivotal role in understanding large-scale biogeographic and phylogeographic phenomena, such as the global latitudinal diversity gradient (LDG), and insights like Wallace's Sarawak Law (Wallace 1855). On the other hand, at a local scale, this same overwhelming species richness in most clades presents a frustrating taxonomic and natural history challenge to document basic biodiversity. In systems where the fundamental units are poorly identified, it is more difficult to assess emergent patterns. This point has been made repeatedly, about the underestimating of biodiversity in less-studied taxonomic groups and habitats (e.g. Middelfart et al. 2016; Sigwart and Garbett 2018), as well as the downstream cascading problems that arise from analyses based on poor taxonomic resolution and accuracy (Bortolus 2008). Understanding the natural history of marine species in SE Asia is critical to broader scientific aspirations of assessing Earth's species richness, evolutionary innovations, and the drivers and limits of diversity and diversification.

The bivalved gastropod family Juliidae is a pan-tropical clade, noted for their exceptional morphology, with a two- 
part symmetrical shell that strongly resembles a bivalve. Several living species and at least one fossil species in this clade were originally described as bivalves (e.g. Crosse 1875) and only recognised as gastropods from live observations in ca. 1960 (Kawaguti and Baba 1959; Baba 1961). Recognising the convergence of this gastropod shell morphology with a deeply divergent clade of molluscs (bivalves) dramatically expanded the idea of disparity among gastropods and remains critically important to understanding the morphological evolution of molluscs (Sigwart 2017; Runnegar and Pojeta 1985)

Most sacoglossan gastropods, including all members of Juliidae, feed on green algae by piercing the outer membrane with their radula and sucking the internal fluids with a muscular pharynx. Their characteristically green body colour and small body size make many sacoglossans highly camouflaged and easily overlooked by field biologists. Investigations of other Sacoglossa in SE Asia have revealed pseudocryptic sibling species with apparently overlapping niches, sometimes co-occurring and even depending on the same food plant (e.g. Krug et al. 2018).

Species of Juliidae occur throughout the tropics, in the Caribbean, SE Asia, Australia, and Pacific islands, including the type locality of the earliest described species of the genus Julia in Hawai'i (Gould 1862; Kay 1962). In Japan (the type locality of the first described species of Berthelinia and the region where living Juliidae were first studied, leading to their recognition as gastropods rather than bivalves), there are at least four species in two genera (Jensen 2007). By contrast, in the generally megadiverse fauna of Malaysia and Singapore, only one species of the family Juliidae has been recorded (Jensen 2015; Jensen and Ong 2018).

In the present study, we compiled observations of Berthelinia singaporensis Jensen, 2015 from field and lab studies, to illuminate its natural history. The aims of the present paper are to consider what aspects of reproductive biology and autecology may limit the potential for further species divergences within this apparently highly specialised bodyplan, and the evolutionary drivers for the bivalved form.

\section{Material and methods}

Live specimens of Berthelinia singaporensis were collected from two sites in peninsular Malaysia, on multiple occasions from March 2015 to July 2018 (Fig. 1). The two sites are Blue Lagoon, Melaka $\left(2^{\circ} 24^{\prime} 53.6^{\prime \prime} \mathrm{N}, 101^{\circ} 51^{\prime} 16.8^{\prime \prime}\right.$ E), in the Malacca Strait, near the city of Port Dickson (hereafter referred to as the "Port Dickson" population), and a second site at the small island of Pulau Merambong $\left(1^{\circ} 18^{\prime} 53.2^{\prime \prime} \mathrm{N}, 103^{\circ} 36^{\prime} 33.5^{\prime \prime} \mathrm{E}\right)$ in the Sungai Pulai Estuary in the Johor Strait between the southern tip of peninsular
Malaysia and the island of Singapore (hereafter the "Merambong" population).

Specimens were obtained by collecting multiple species of green algae in the genus Caulerpa, and the gastropods were recovered either by manually examining the algae or by holding live algal samples in small aquaria and observing gastropods crawling on the algae or transparent surface of the aquarium over several days. Animals recovered from Merambong, and animals and Caulerpa from Port Dickson were returned to the International Institute of Aquaculture and Aquatic Sciences (IAQUAS) facility of Universiti Putra Malaysia, in Port Dickson. Multiple species of Caulerpa co-occur at both field sites. Our identification of Caulerpa species was determined with some caution based on gross morphology and comparison with available regional lists. Berthelinia specimens were identified to species by comparison with the original description (Jensen 2015; K. Jensen pers. comm.); analysis of standard barcode marker DNA fragments from $B$. singaporensis specimens from the two study populations indicated no significant divergence (unpublished analyses: McCarthy 2017).

The abundance of Caulerpa is variable throughout the year at both sites. To assess potential seasonality of Caulerpa availability, we re-analysed existing data for a time series of algal coverage at Merambong. At this site, an ongoing long-term monitoring project has established a 100-m permanent fixed transect, parallel to the shore at approximately chart datum, which is sampled at low spring tides (Wong, unpubl. data). Quadrats at fixed positions at $5 \mathrm{~m}$ intervals were each captured as a highresolution photo-quadrat of $1 \mathrm{~m}^{2}$. For analysis, each image is demarcated into a $10 \times 10$ grid. Each grid area is scored for the presence of algal cover covering at least half of that $10 \mathrm{~cm} \times 10 \mathrm{~cm}$ area. Percent cover on the shore is based on a cumulative average of the scores for each of 20 quadrats. This transect was sampled at twomonth intervals from April 2015 to April 2017.

For observations of live Berthelinia, experimental animals were kept in the I-AQUAS hatchery, housed in static seawater (i.e. not connected to the available flow-through seawater supply) in $500 \mathrm{~mL}$ containers with aeration at ambient temperature (typically $27-29^{\circ} \mathrm{C}$ ), and provided with small amounts of Caulerpa spp. Behavioural observations were used to select the most appropriate food, assessing a general tendency of animals to congregate on a particular plant in a volume of mixed Caulerpa samples held in aquaria, or observations that animals begin feeding on a single alga within a water basin in preference to continued exploration of the environment. Caulerpa lentilifera was primarily used for feeding, but animals laying eggs were transferred to Caulerpa spp. with flat surfaces (C. subserrata, C. cf. lamourouxii) to enable better observation of egg masses. 


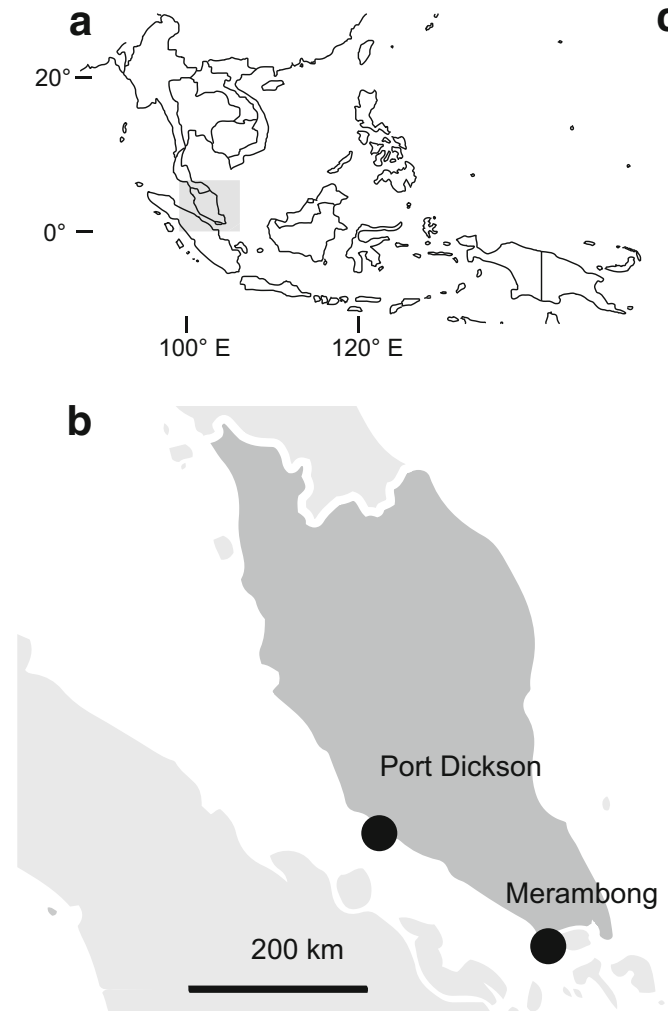

Fig. 1 Habitat context for Berthelinia singaporensis. a Regional map, with the area of peninsular Malaysia indicated by a shaded box; $\mathbf{b}$ Map of peninsular Malaysia showing location of two study sites included here;

When egg masses were observed with captive animals, the egg masses were scraped off the alga and moved to Petri dishes with seawater. Daily observations and photographs for developing embryos were used to record the timing of transitions between successive embryonic stages. Embryos were photographed with an Olympus BX43F compound microscope and Olympus DP22 camera with Olympus cellSens Standard V1.14 image processing software.

When the first veliger was observed hatching from an egg mass, the whole remaining egg mass and any freeswimming larvae were transferred to a $250 \mathrm{~mL}$ beaker with aerated seawater and provided with a few drops of concentrated Nannochloropsis microalgae from established lab cultures. After the majority of larvae were observed swimming, a short stem of $C$. cf. lamourouxii was added to the container to encourage settlement and feeding. Larvae that successfully settled were monitored multiple times daily until they completed the final metamorphosis to the terminal bivalved adult form. Thereafter, juveniles were returned to larger holding tanks (plastic basins of approximately $4 \mathrm{~L}$, with static aerated seawater) to maintain the captive population. Over approximately three years of this study, the captive population was repeatedly re-stocked from both field collection and captive

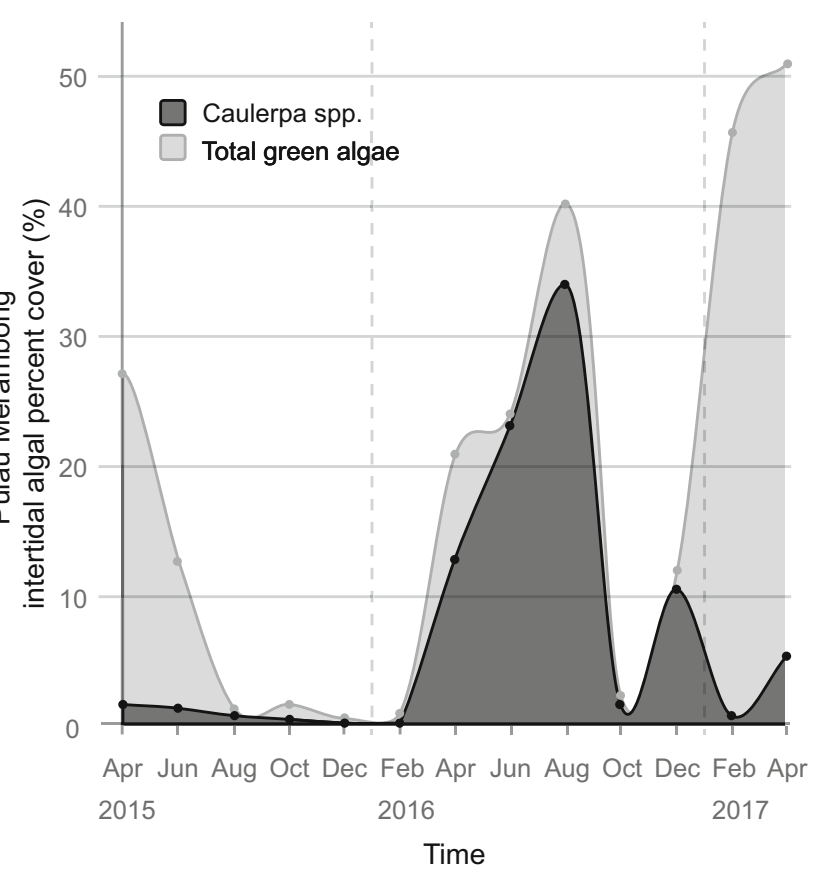

c Fluctuating abundance of the siphonous green algae Caulerpa spp. and total intertidal algal cover measured in photo quadrats at Pulau Merambong over a two-year period

reproduction and the number of captive specimens varied from a few individuals to up to 50 adults across both populations.

\section{Results}

\section{Habitat}

We found diverse Caulerpa spp. at both field sites; if our identification of $C$. lamourouxii is correct, this expands the number of Caulerpa taxa recorded from the Port Dickson site to 9 species (Table 1; Asmida et al. 2017). A previously published list of macroalgae at Merambong Shoal, a seagrass meadow adjacent to our field site, included three species of Caulerpa, and we have observed seven other taxa (Table 1; Muta Harah et al. 2014). A regional compilation for SE Asia included seventeen species of Caulerpa in Malaysia but noted that many new species have been described recently in the region (Phang et al. 2016). Discrepancies in species lists recorded may relate to the fluctuating populations of green seaweed. The abundance of Caulerpa spp. at Merambong varied from $0 \%$ cover to over $33 \%$ cover in a two-year period (Fig. $1 \mathrm{c})$; general algal coverage fluctuates irregularly and there is 
Table 1 Diversity of the siphonous green algae Caulerpa in two sites in peninsular Malaysia: (+) recorded in the present study; (1) recorded at Port Dickson by Asmida et al. (2017); (2) recorded at Merambong by Muta Harah et al. (2014); (*) new species in this study or those cited, not included in the Caulerpa species list for Malaysia by Phang et al. (2016).
(N.B. Caulerpa chemnitzia listed here as a new record for both sites has formerly been called $C$. peltata; Belton et al. 2014.) The final column shows those that were experimentally verified as food for Berthelinia singaporensis

\begin{tabular}{|c|c|c|c|}
\hline Species & $\begin{array}{l}\text { Blue Lagoon, Port } \\
\text { Dickson }\end{array}$ & $\begin{array}{l}\text { Merambong, } \\
\text { Johor Strait }\end{array}$ & $\begin{array}{l}\text { Berthelinia singaporensis } \\
\text { observed feeding }\end{array}$ \\
\hline Caulerpa chemnitzia (Esper) J.V. Lamouroux, 1809 & + & + & \\
\hline C. cf. lamourouxii (Turner) C. Agardh, 1817 & $+^{*}$ & & $x$ \\
\hline C. lentillifera J. Agardh, 1837 & $+{ }^{1}$ & + & $x$ \\
\hline C. manorensis Nizamuddin, 1964 & & $2 *$ & \\
\hline C. mexicana Sonder ex Kützing, 1849 & & + & \\
\hline C. microphysa (Weber-van Bosse) Feldmann, 1955 & 1 & + & \\
\hline C. racemosa (Forsskål) J. Agardh, 1873 & $+{ }^{1}$ & + & $\times$ \\
\hline C. racemosa var macrophysa (Sonder ex Kützing) W.R. Taylor, 1928 & & + & \\
\hline C. serrulata (Forsskål) J. Agardh, 1837 & $+{ }^{1}$ & + & $\times$ \\
\hline C. sertularioides (S.G. Gmelin) M.A. Howe, 1905 & $+{ }^{1}$ & $+^{2}$ & $x$ \\
\hline C. subserrata Okamura, 1897 & $1 *$ & & \\
\hline C. taxifolia (M. Vahl) C. Agardh, 1817 & & 2 & \\
\hline C. verticillata J. Agardh, 1847 & 1 & & \\
\hline
\end{tabular}

no clear or consistent seasonality to the episodic blooms of Caulerpa.

Berthelinia singaporensis does not have a specific dependency on one species of food plant. Adults and egg masses have been found on several species of Caulerpa in field and lab conditions, and the animals demonstrate little apparent preference for certain species among their potential food taxa. In captivity, we have found them consuming Caulerpa racemosa, C. lentellifera, $C$. serrulata, $C$. sertularioides, and $C$. cf. lamourouxii, with active feeding confirmed based on the marks left on the surface of their food plants (Table 1). These notably include Caulerpa species with both pinnate fronds and grape-like spherical ramuli. Furthermore, we have not noticed any preference for specific places on the food plant where the gastropods rest in captivity. For $B$. singaporensis on $C$. racemosa, we found feeding radular marks on the tips of the ramuli, between assimilators (branches) and the main stolon of the alga, and on the stolon itself (Fig. 2a).

\section{Life cycle}

The size of individuals recovered in field-collected Caulerpa ranged from 1.5 to $3 \mathrm{~mm}$ in shell length. Individuals held in captivity apparently achieve larger shell sizes, up to a maximum of $5 \mathrm{~mm}$. A group of over 20 adult animals of similar size, collected together in April 2016, maintained apparently good health and growth in the lab for a period of six months and then all died within a short interval in early October 2016, although the group was divided into independent aquaria (in different buildings with separate seawater supply). We examined a total of 50 egg masses laid by animals kept in our long-term captive colony, to determine the precise number of eggs, and found that the number of egg capsules per egg mass ranged from 8 to 108 with mean 46.6 egg capsules per egg mass (Fig. 3). The diameter of the uncleaved egg within the capsule was approximately $83 \mu \mathrm{m}$. Our repeated observations of the developing egg masses produced by animals collected in Merambong all closely followed a consistent developmental calendar (Table 2; Fig. 4). The developing embryos experience a very brief trochophore phase in ovo before metamorphosing to a typical gastropod veliger at about $72 \mathrm{~h}$ after fertilisation. The larvae experience another secondary and terminal metamorphosis after settlement, to achieve the adult bivalved form.

At approximately 10 days after fertilisation, larvae hatch as swimming gastropod veligers with a small, coiled shell (Fig. 5). The veligers can retract into the shell and produce an elastic mucous tether that they can "glue" to the substratum. In the absence of surface agitation through aeration, the larval protoconch sticks to the surface (Wisely 1962; Grahame 1969; Jensen and Ong 2018), but this is an effect of surface tension, not deliberate adhesion, and the veligers are unable to 
Fig. 2 Berthelinia singaporensis, with individual animals indicated by arrows. a On Caulerpa cf. racemosa; b On Caulerpa cf. sertularioides. Animal size is approximately $4 \mathrm{~mm}$
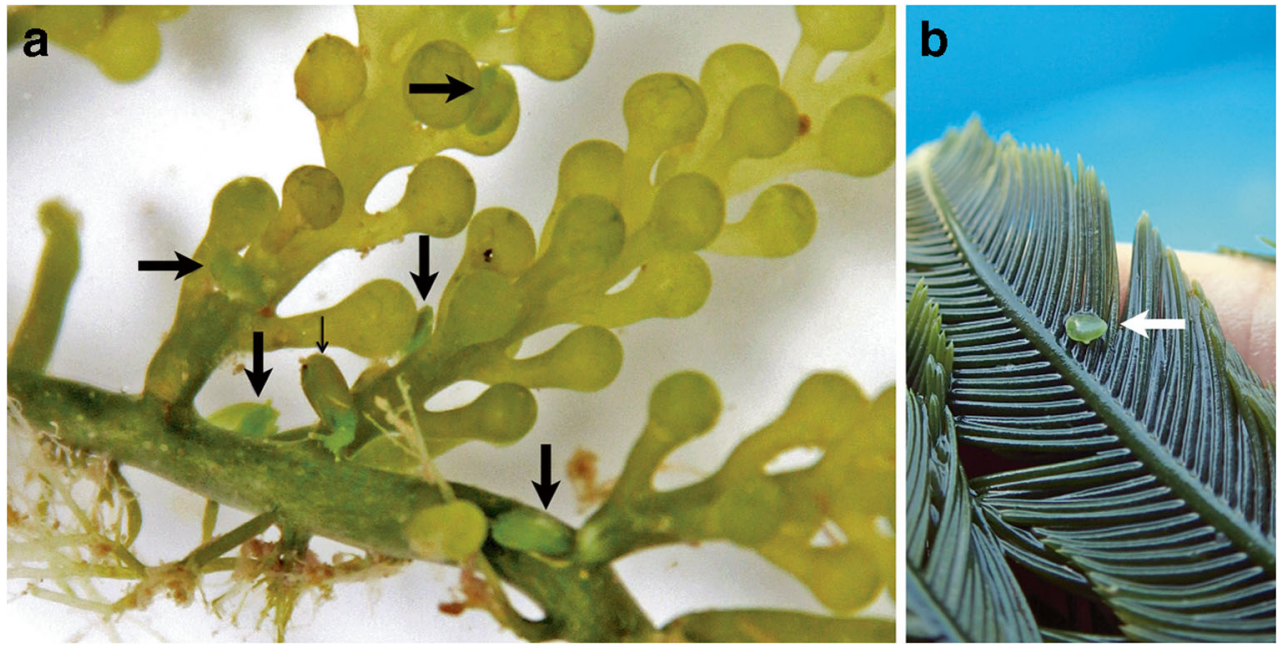

escape from the surface and will die there without intervention. This swimming (dispersal) phase lasts for 1-3 days before the animals settle and begin feeding. In some cases, in the presence of healthy Caulerpa, swimming lasted for less than $24 \mathrm{~h}$ before settlement. Without access to Caulerpa, the larvae continue swimming, but, from our preliminary observations, survivorship declines rapidly after 8-9 days even in the presence of suspended microalgae.

At the settlement, within $24 \mathrm{~h}$, the larvae shed the ciliated velum and begin feeding continuously, piercing the algal wall and sucking on the interior juices (Figs. 5, 6). The embryos and larvae are colourless and nearly transparent, and begin to turn visibly green after they have been feeding for several days and complete the second metamorphosis to the bivalved form (Fig. 6c). This final metamorphosis occurs $24-48 \mathrm{~h}$ after settlement, when the larva sheds its operculum, and the growing margin of the shell splits to form the second, right valve (Fig. 6). In the next several days after the final metamorphosis, both sides of the shell grow equally (the left shell extends from the coiled protoconch, the right shell extends from the initial flap or "visor" of shell formed at the second, terminal metamorphosis).

Fig. 3 Egg masses of Berthelinia singaporensis. a New egg mass and mother; note white coiled protoconch visible at top of valve (left valve in view, animal length is approximately $4 \mathrm{~mm}$ ); b Sizefrequency of egg masses observed in captivity
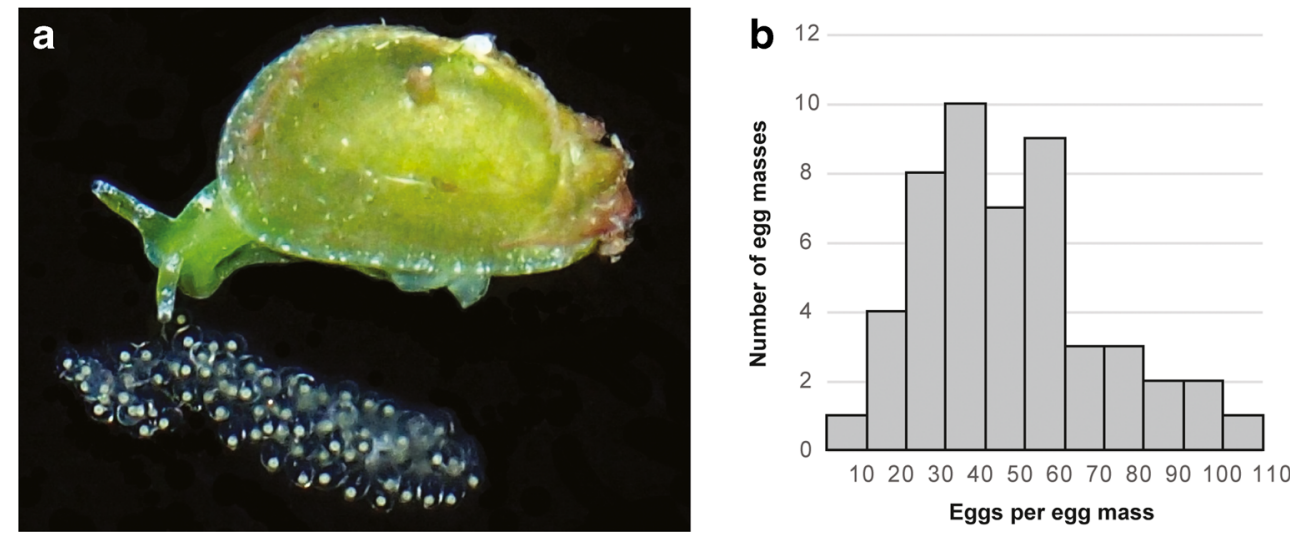
Table 2 Development of Berthelinia singaporensis, observed in batches at both 26 and $28{ }^{\circ} \mathrm{C}$

\begin{tabular}{|c|c|c|c|}
\hline Stage & Day & Approximate hours post-fertilisation & Mean size $( \pm$ s.d. $)$ \\
\hline Fertilisation & 0 & & \\
\hline 2 cell & 0 & $4 \mathrm{hpf}$ & \\
\hline 8 cell & 0 & $8 \mathrm{hpf}$ & \\
\hline 16 cell & 0 & $11 \mathrm{hpf}$ & \\
\hline Blastula & 1 & $27 \mathrm{hpf}$ & \\
\hline Gastrulation & 1 & $33 \mathrm{hpf}$ & $92.31 \pm 3.13 \mu \mathrm{m}, n=30$ \\
\hline Trochophore (swimming) & 2 & $52 \mathrm{hpf}$ & \\
\hline Early veliger & 3 & $76 \mathrm{hpf}$ & \\
\hline Shelled veliger & 4 & & \\
\hline Veliger with organ systems & 5 & & $148.88 \pm 9.4 \mu \mathrm{m}, n=30$ \\
\hline Fully developed veliger, appears ready to hatch & 6 & & Shell length $\sim 220 \mu \mathrm{m}$ (day 8 ) \\
\hline Hatching & 10 & & Shell length $244.11 \pm 12.29 \mu \mathrm{m}, n=30$ \\
\hline Swimming & 10 & & \\
\hline Settled on Caulerpa and feeding & 12 & & \\
\hline Final metamorphosis, bivalved shell and shed operculum & 13 & & \\
\hline
\end{tabular}

which may slightly confound our impression of preference; however, B. singaporensis has been observed feeding on at least five species in laboratory conditions (Table 1). The question of food preferences, as well as larval dispersal, is relevant to issues of diversification, and we will return to this idea below.

Observations of spawning and development of Juliidae have been reported for several species. The development of $B$. singaporensis was also recently described from another population by Jensen and Ong (2018), and our findings corroborate their observations. Details of development have also been reported from Berthelinia limax (Kawaguti and Baba, 1959) (Kawaguti and Yamasu 1960), Berthelinia caribbea Edmunds, 1963 (e.g. Wisely 1962; Davis 1967), and Julia japonica Kuroda and Habe, 1951 (Kawaguti and Yamasu 1966), and some additional observations in the original description of Berthelinia ganapati Sarma, 1975. Kawaguti and Yamasu (e.g. 1960) kept long-term captive colonies of B. limax; they reported a mean egg mass size of 138 eggs (ranging from 11 to 470 eggs) in a sample of 465 egg masses. Observations of Berthelinia australis (Burn, 1960) and several studies on the smaller species $B$. caribbea reported egg masses of less than 100 eggs (Wisely 1962; Edmunds 1963; Davis 1967; Grahame 1969). Published observations of $B$. ganapati were based on a single captive pair, which were kept in the laboratory for only five weeks and laid thousands of eggs at an average of 281 eggs per day, although none of these eggs successfully hatched (Sarma 1975). Interestingly, the first documented observation of B. singaporensis included a report of an egg mass of more than 200 eggs (Jensen 2015). These reports of egg mass sizes from short-term isolated specimens are dramatically larger than observations from healthy captive populations (Kawaguti and Yamasu 1960; herein), and the detailed observations of spawning output in B. limax suggested a negative correlation between food quality and egg mass size (Kawaguti and Yamasu 1960). These differing rates of egg laying may be an effect of maternal body size, or increased spawning effort may be potentially associated with stress in these species.

The developmental timetable is substantially shorter in B. singaporensis than that reported for B. limax, as would be expected in comparing this tropical species to the relatively temperate conditions of other studies in Japan. Kawaguti and Yamasu (1960) noted that the developmental cycle of B. limax did not appear seasonal and was not strongly influenced by changes in temperature, including winter temperatures around $10{ }^{\circ} \mathrm{C}$, which agrees with our informal observations over a much smaller range of temperature conditions. Kawaguti and Yamasu (1960) noted that the developmental period (time from spawning to hatching) was shorter in egg masses removed from the food plant $(\sim 33 \mathrm{~d})$ compared to those left on the alga ( $\sim 43 \mathrm{~d})$. We did not repeat this experiment, and all our observations relate to egg masses that were removed for observation.

The developmental timetable we observed for $B$. singaporensis matched the prior reports for $B$. singaporensis (Jensen and Ong, 2018) and was very similar to observations of B. australis. At $21^{\circ} \mathrm{C}, B$. australis began developing velar lobes at $70 \mathrm{hpf}$ (Wisely 1962). As trochophores and early-stage veligers, the $B$. singaporensis larvae are very active within the egg capsule. 

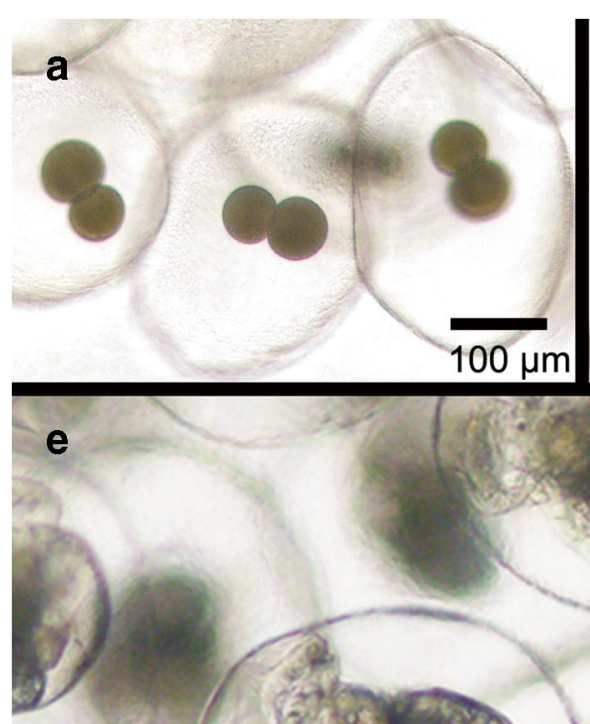

b

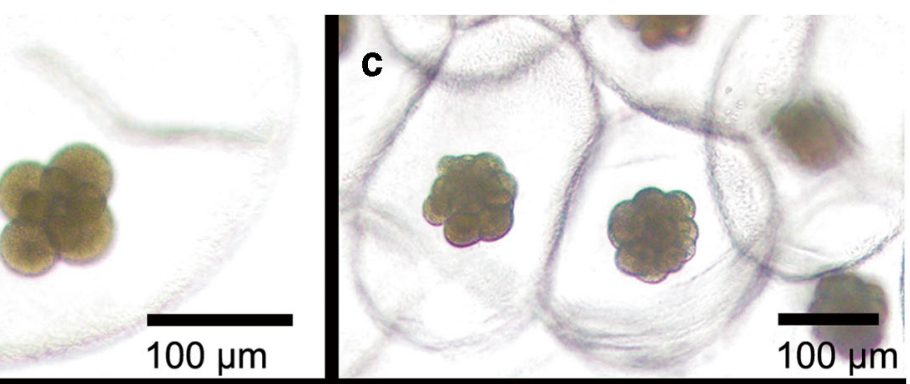

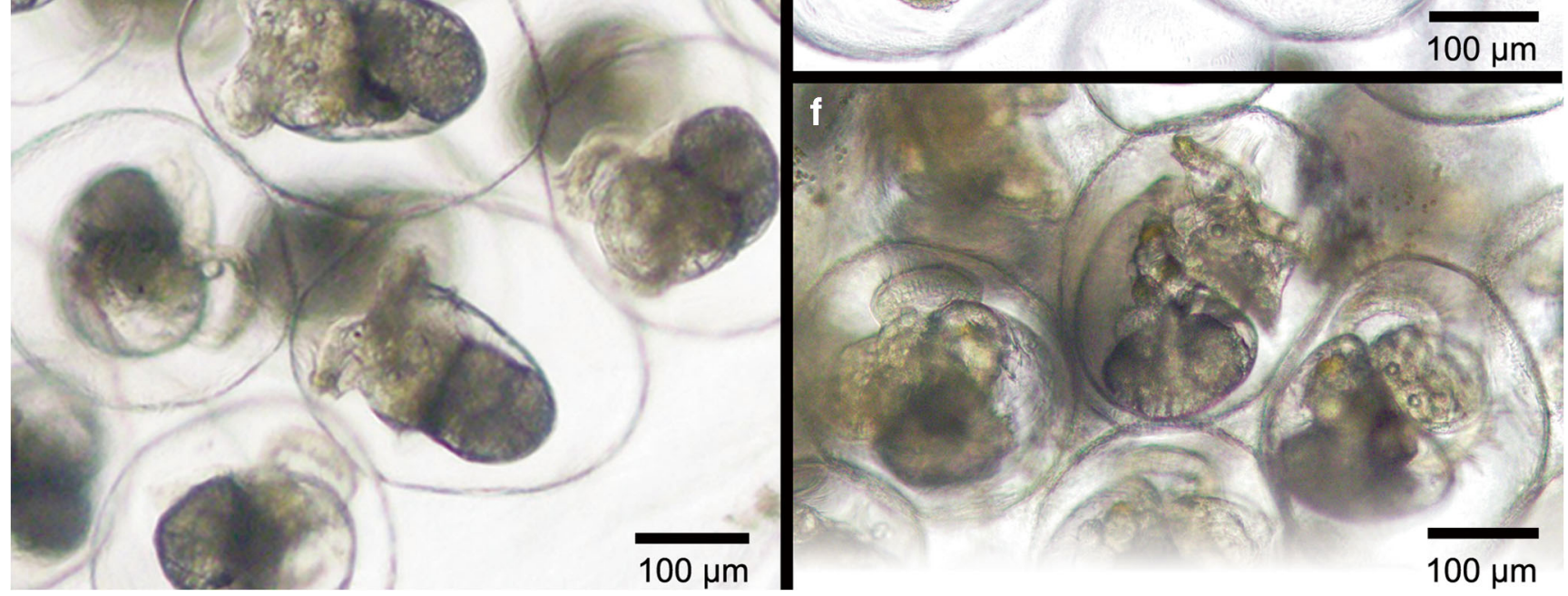

Fig. 4 Some developmental stages of Berthelinia singaporensis embryos. a First cleavage; b Second cleavage; $\mathbf{c}$ Third cleavage; $\mathbf{d}$ Early trochophore, with cilia visible; e Veliger, with developing organ systems, and eyespots; f Fully developed veliger

The veligers grow and actively swim within the egg capsule over the next several days after the first metamorphosis from trochophore to veliger. At about 6 days post-fertilisation, they appear to be fully developed and ready to hatch, have grown to maximum possible size and can no longer swim or turn within the egg, and become inactive. This was slower in a previous study of the same species, which reported full size and slower-moving intracapsular veligers at 10 days
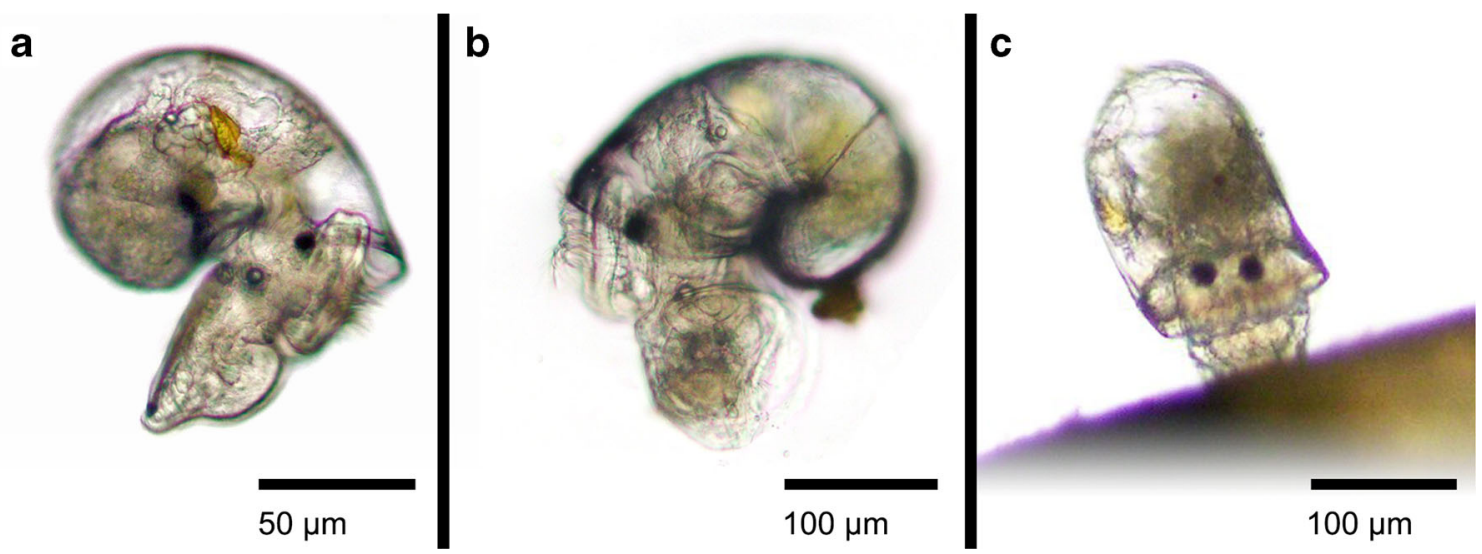

Fig. 5 Veliger larvae of Berthelinia singaporensis. a Newly hatched veliger; $\mathbf{b}$ Swimming veliger, with cells of Nannochloropsis visible in the gut through the transparent body; c Recently settled veliger on Caulerpa 
Fig. 6 Second (terminal) metamorphosis of Berthelinia singaporensis, transforming from coiled to bivalved form. a Larva feeding on Caulerpa, noting the veliger operculum (op) still in place, and arrowhead indicating the first "flap" of separated shell material that will expand to form the second (right) valve; b Larva immediately after shedding the operculum, visible here (end-on) and as dark oblique line (indicated op); c Complete secondary metamorphosis, with two equal teleoconch valves and the coiled protoconch. Asterisks (*) indicate individual cells in a line of cells now visible in the distal edge of the mantle that are green, apparently sequestered from the food plant
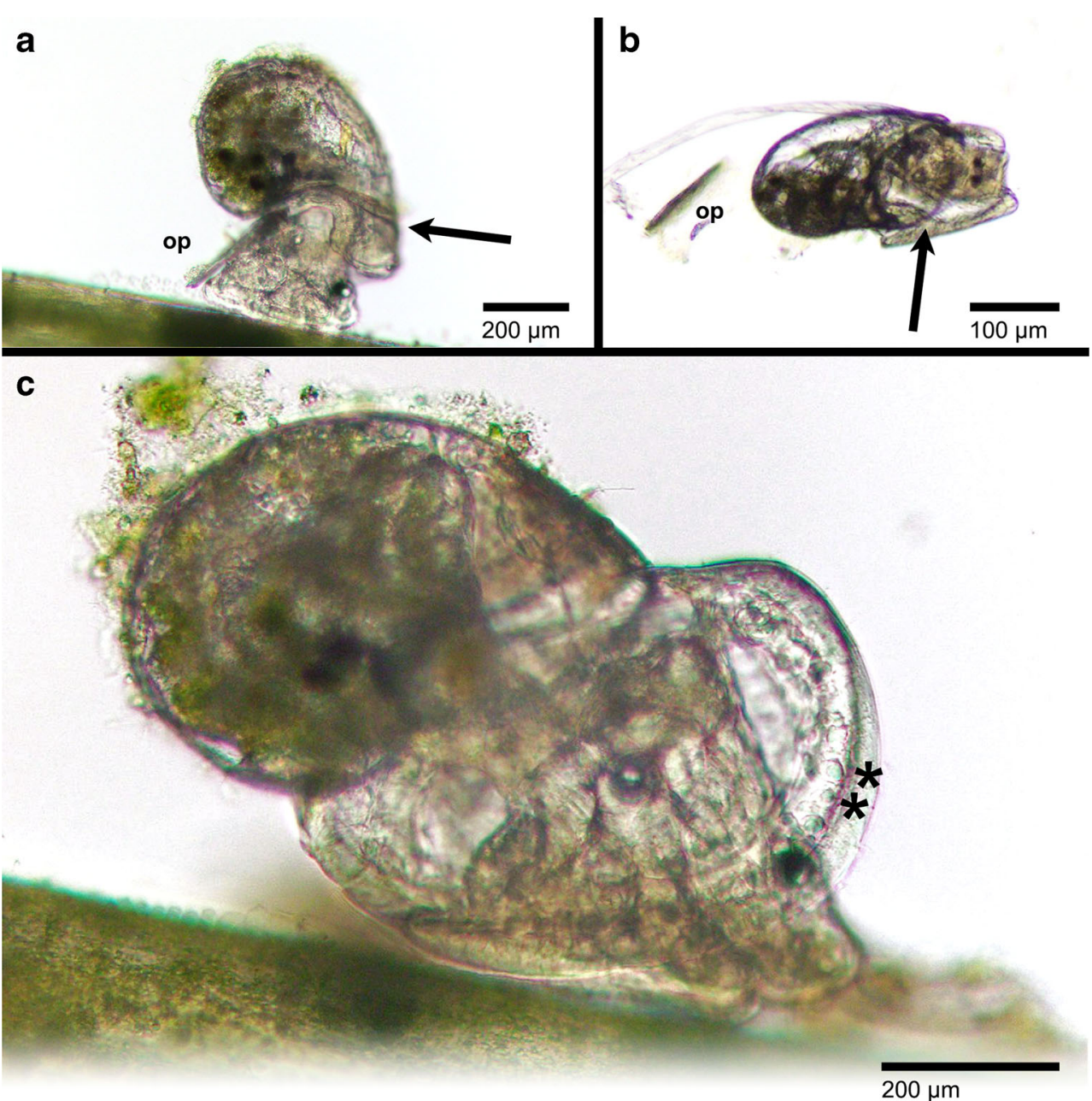

(Jensen and Ong 2018). The veligers nonetheless remain within the egg capsule for 3-4 days beyond that point, hatching at 9-10 days post-fertilisation (10-13 days in a prior study; Jensen and Ong 2018). This is similar to $B$. australis hatching at 13 days (Wisely 1962) and considerably accelerated compared to the 30-40 d development reported for B. limax (Kawaguti and Yamasu 1960). The following period of 3-4 d to secondary metamorphosis is similar in all reported species: B. singaporensis (herein), B. limax (Kawaguti and Yamasu 1960), as well as B. caribbea (Grahame 1969).

The estimated lifespan of $B$. limax is around 220 days (Kawaguti and Yamasu 1960), and much shorter for the smaller Caribbean species B. caribbea (Grahame 1969), and we infer that the lifespan of $B$. singaporensis is likewise less than 1 year.

\section{Bivalved gastropods}

The usual form of these gastropods naturally leads to a question about adaptive significance of the bivalved shell form. We can propose several more or less unsatisfactory hypotheses, which we will discuss below, related to (a) crypsis, (b) mobility, and, most plausibly, (c) tethering.

Sacoglossans are highly camouflaged, matching the colour and often the texture of their preferred algal substrata (e.g. Baumgartner et al. 2009). Captive B. limax were observed to turn a darker green shell colour later in life, at about the same size as they apparently reach sexual maturity (Kawaguti and Yamasu 1960). We did not see a clear colour change or gradient in B. singaporensis, but we cannot exclude this possibility; individuals do vary in colour, but it is not clear whether this is directly related to age, or food plant species, or intrinsic morphological variation.

Most species of Caulerpa have distinct spherical, bubblelike ramuli projecting in clusters from a stem called an "assimilator" (Belton et al. 2014). In some species, these "bubbles" are similar in size to adult $B$. singaporensis. This is most noticeable in the alga $C$. racemosa (Fig. 2a). The verified food algae for $B$. singaporensis include many forms, including those with branching fronds that offer no textural or morphological crypsis (Fig. 2b, Jensen 2015: figure 1F). Another Caulerpa species consumed by the gastropods, $C$. lentillifera, has very small ramuli arranged in tightly 
packed or grape-like clusters. Another point that refutes the idea of visual camouflage may be that the ramuli of these Caulerpa spp. are oblately spherical, but the shell of Berthelinia is laterally flattened.

Rather than substrate-matching, the sail-like laterally flattened shape of $B$. singaporensis may be advantageous for navigating between these bubble structures or other epibiota on Caulerpa. Their flattened body structure is perfect to "sail" and hide between ramuli of $C$. lentillifera, but, again, the gastropods can be found on a wide variety of Caulerpa spp. in the field (Table 1). Individuals hidden among the ramuli could, speculatively, have higher survivorship than others. However, this does not provide a strong or plausible adaptive hypothesis. This idea is undermined by the lack of an exclusive preference by B. singaporensis for Caulerpa with that type of structure, and that they do not stay within those camouflaging structures when they are available. Visual crypsis and issues of mobility do not seem to provide plausible mechanisms for any adaptive significance of the bivalved shell.

Berthelinia singaporensis attaches to the substratum by a thin mucous tether which is secreted by the foot. The distal end of the tether is extremely sticky, but the length of the string is not adhesive. The tether or string is very fine (only a few micrometres wide) and highly elastic; one adult individual with a shell length of $3 \mathrm{~mm}$ had a tether that we stretched to $124 \mathrm{~mm}$ before breaking. The veliger larvae are able to produce a tether at least as early as settlement and apparently before shedding the velum (i.e. when the larva is still in a coiled form, before the terminal metamorphosis, they can already tether themselves to the substratum). The attachment point of the tether remains adhesive after it is dislodged and after fixation and will stick to anything it contacts. For example, preserved samples of veliger larvae frequently become tethered to the internal wall of a glass pipette. However, this is not unique to Berthelinia, at larval or adult stages; it is a feature that Juliidae presumably inherited from an earlier sacoglossan ancestor.

Many other diverse sacoglossan gastropods also produce similar adhesive mucous tethers (e.g. Clark 1982; P. Krug, pers. comm.). Sacoglossans feed on green algae, which are restricted to shallow depths and prone to movement and disturbance from wind, waves, and tidal emersion. The tether is an effective means to avoid dislodgement in a turbulent environment. In the bivalved form, adults and juveniles use this tether to attach to the food plant while feeding or resting. The bivalved shell can close completely while the tether remains attached. We suggest that, inasmuch as the bivalved form may be interpreted as adaptive, the key innovation may be that this form allows the animal to fully retract within a protective shell while maintaining the attachment of the tether. The critical feature of a bivalve form in Juliidae is that a bivalved shell is optimal for attachment with a byssus.

\section{Drivers for species diversity}

Much of the earlier research on development in Juliidae was driven by the idea that these animals may represent a "missing link" or transitional form that could indicate the polarity of ancestral forms between gastropods and bivalves (Kawaguti 1959). After a further 60 years of study on molluscan evolution and phylogenetics, the interpretation of the importance of this clade is profoundly different (Sigwart and Lindberg 2014). Interestingly, the existence of bivalved forms of gastropods, a shell form derived independently in Bivalvia, was a key point of evidence used to first recognise the extinct molluscan group Rostroconchia as a separate taxonomic class, as they also have a univalved larval shell but a bivalved adult shell (Pojeta Jr et al. 1972). The bivalved gastropod form should not be dismissed as a unique oddity; rather, it is representative of broader trends within Mollusca and the rapid evolution of highly disparate morphologies (Sigwart 2017).

Sacoglossans are considered a "highly specialised" clade, in reference to the synapomorphies of their pharyngeal morphology and the green body colour, and some have very specific associations with their food alga (e.g. Baumgartner et al. 2009; Jensen 2015). The anatomy of sacoglossan gastropods is very different to other heterobranch gastropods (Jensen 2011), and molecular evidence also indicates Sacoglossa, and, indeed, Juliidae, represents a relatively recently derived and rapidly evolving branch (Schrödl 2014; Krug et al. 2015; Pabst and Kocot 2018). Juliidae may be a fast-evolving branch within that already divergent group, resulting in low signal quality in early molecular phylogenetic analyses (Händeler and Wägele 2007).

Members of Juliidae live in tropical regions all over the world and represent over 22 species with many more undescribed (McCarthy 2017). The genus Berthelinia s.l. comprises species in several potentially distinct genera (Edenttellina, Midorigai, Tamanovalva), which are currently considered junior synonyms but often still used in identification (Grove and de Little 2014; Wägele and Martin 2014). There is, thus, some modest diversity in the family. Over the history of work on this clade, the largest number of species were found first in Australia and Japan, and the lack of records in other regions with suitable habitat certainly reflects lower sampling effort (Middelfart et al. 2016). At the two study sites examined here, B. singaporensis is the only shelled sacoglossan that is obligately feeding on and living on Caulerpa. Many species of micromolluscs, and the juveniles of larger species, occupy Caulerpa as a habitat and substrate (Sigwart and McLean 2017). The multiple species of Caulerpa in these study sites and the coral rubble environment create a complex three-dimensional habitat space that is expansive when considered at the scale of shelled sacoglossans. Although the global species richness of this family is not overwhelming, it is slightly counter-intuitive that after some 
significant sampling effort in peninsular Malaysia, we still find only one species of Juliidae.

A large number of sacoglossan species remain undescribed, and ongoing work continues to reveal both new discoveries and cryptic species worldwide (e.g. Carmona et al. 2011; Krug et al. 2013; Espinoza et al. 2014; Krug et al. 2018). Jensen (1997) predicted that there might be a co-evolutionary or correlative relationship between sacoglossan diversity and the evolution of their food plants and that these relationships might have some predictive power about the number of species in genus- or family-level groups within Sacoglossa. Prior reports on a variety of sacoglossan taxa have noted both highly specialised feeding behaviours, other species that utilise a variety of food plants, and some confusion over the difference between algae used as substrata and not ingested (Baumgartner et al. 2009; Händeler and Wägele 2007). Caulerpa spp. contain phytotoxins, including caulerpenyne, in concentrations that differ among species (Meyer and Paul 1992). Berthelinia singaporensis feeds on multiple species, including those with relatively low (e.g. C. lentillifera) and high concentrations of secondary metabolites (C. sertularoides; Baumgartner et al. 2009). Some sacoglossan species have more specific associations with their food plant than others, which is concordant with the diversification of a rapidly evolving large clade.

Our results provide direct evidence that $B$. singaporensis will feed on at least five species of Caulerpa, while previous records of the food plants for any other Berthelinia sp. included one or at most two species of Caulerpa (Händeler and Wägele 2007). We note that no prior study with access to a high-quality, long-term captive population of bivalved gastropods has been exposed to the species diversity of Caulerpa found in peninsular Malaysia, which limits the ability and relevance to test the preferences of other Juliidae. The fact that they are adapted, apparently, to maintain a byssal attachment to their food plant may explain the broad species ranges, through distribution by rafting. The ability to switch between food plant species is no doubt advantageous in these environments with erratic availability of Caulerpa.

The species in tropical ecosystems tend to have specialised niches more frequently than in temperate ecosystems (Stevens 1989; Jablonski et al. 2013). Feeding on one genus of green algae may be relatively specialised, but in the locally relevant context in coastal Malaysia, this hyperdiverse region for shallow marine fauna and flora, the genus Caulerpa provides a relatively broad niche. As niche space becomes more crowded in increasingly species-rich habitats, the bounds of what is specialised become narrower and more specialised. Although the form of bivalved gastropods is unusual compared to other gastropods, B. singaporensis is functionally a relative generalist, and this may limit the tendency toward sympatric speciation.
Acknowledgements We thank Kathe Jensen and Pat Krug for illuminating discussion on sacoglossans. For fieldwork and lab support, we are grateful to the staff at I-AQUAS, Jun-Chin Teh, Serina Rahman, and the members of Kelab Alami, and participants in a UPM training workshop on molluscan taxonomy held in Johor in May 2017. Mr. Nadzmi Akmal Mohd Khair (UPM) also contributed to the lab work. Crucial early support for this work was provided by Jarina Mohd Jani (Universiti Malaysia Terengganu) and James (Hamish) Mair (Heriot-Watt University) and their colleagues who kindly permitted us to participate in an early-career researchers' workshop in Kuala Teregganu, Malaysia.

Funding This research was supported by the British Council NewtonUngku Omar Fund (travel support to both NLW and JDS in 2015 and 2016), by the European Union's Horizon 2020 Research and Innovation Programme (grant agreement no. H2020-MSCA-IF-2014-655661 to JDS), and by the Country Garden Pacificview Sdn Bhd (research contract 2015-2020 Vot. 6300813).

\section{Compliance with ethical standards}

Conflict of interest The authors declare that they have no conflict of interest.

Ethical approval All applicable international, national, and/or institutional guidelines for the care and use of animals were followed by the authors.

Sampling and field studies All necessary permits for sampling and observational field studies have been obtained by the authors from the competent authorities and are mentioned in the acknowledgements, if applicable.

Data availability The datasets generated during and/or analysed during the current study are available from the corresponding author upon reasonable request.

Open Access This article is distributed under the terms of the Creative Commons Attribution 4.0 International License (http:// creativecommons.org/licenses/by/4.0/), which permits unrestricted use, distribution, and reproduction in any medium, provided you give appropriate credit to the original author(s) and the source, provide a link to the Creative Commons license, and indicate if changes were made.

\section{References}

Asmida I, Noor Akmal AB, Ahmad I, Sarah Diyana M (2017) Biodiversity of macroalgae in Blue Lagoon, the Straits of Malacca, Malaysia and some aspects of changes in species composition. Sains Malaysiana 46:1-7

Baba K (1961) On the identification and the affinity of Tamanovalva limax, a bivalved sacoglossan mollusc in Japan. Publ Seto Mar Bioi Lab 9:37-62

Baumgartner FA, Motti CA, de Nys R, Paul NA (2009) Feeding preferences and host associations of specialist marine herbivores align with quantitative variation in seaweed secondary metabolites. Mar Ecol Prog Ser 396:1-12

Belton GS, van Reine WF, Huisman JM, Draisma SG, D Gurgel CF (2014) Resolving phenotypic plasticity and species designation in the morphologically challenging Caulerpa racemosa-peltata complex (Chlorophyta, Caulerpaceae). J Phycol 50:32-54

Bortolus A (2008) Error cascades in the biological sciences: the unwanted consequences of using bad taxonomy in ecology. AMBIO 37(2): 114-118

Burn R (1960) Australian bivalve gastropods. Nature 187:44-46 
Carmona L, Malaquias MAE, Gosliner TM, Pola M, Cervera JL (2011) Amphi-Atlantic distributions and cryptic species in sacoglossan sea slugs. J Molluscan Stud 77:401-412

Clark KB (1982) A new Aplysiopsis (Opisthobranchia: Hermaeidae) from central Florida, with a brief summary of the ceratiform families of the order Ascoglossa (= Sacoglossa). Bull Mar Sci 32(1):213-219

Crosse H (1875) Description du nouveau genre Berthelinia. J Conchyliologie, Paris 23:79

Davis C (1967) A study of the hatching process in aquatic invertebrates, XXIV. Emergence of veliger larvae from eggs in gelatinous masses laid by some Jamaican gastropods. Malacologia 5:229-309

Edie SM, Jablonski D, Valentine JW (2018) Contrasting responses of functional diversity to major losses in taxonomic diversity. Proc Natl Acad Sci 2018:201717636

Edmunds M (1963) Berthelinia caribbea n. sp., a bivalved gastropod from the West Atlantic. Zool J Linnean Soc 4:731-739

Espinoza E, DuPont A, Valdés Á (2014) Molecular data reveal an undescribed cryptic species of Costasiella Pruvot-Fol, 1951 (Euthyneura: Sacoglossa: Limapontidae) in the Bahamas. Am Malacol Bull 32:173-182

Gould A (1862) Descriptions of new genera and species of shells. Boston Soc Nat Hist Proc 8:280-285

Grahame J (1969) The biology of Berthelinia caribbea Edmunds. Bull Mar Sci 19:868-879

Grove SJ, de Little R (2014) The coastal marine mollusc fauna of King Island, Tasmania. Pap Proc R Soc Tasmania 148:17-42

Händeler K, Wägele H (2007) Preliminary study on molecular phylogeny of Sacoglossa and a compilation of their food organisms. Bonn Zool Beitr 55:231-254

Jablonski D, Belanger CL, Berke SK, Huang S, Krug AZ, Roy K, Tomasovych A, Valentine JW (2013) Out of the tropics, but how? Fossils, bridge species, and thermal ranges in the dynamics of the marine latitudinal diversity gradient. Proc Natl Acad Sci 110: 10487-10494

Jensen KR (1997) Evolution of the Sacoglossa (Mollusca, Opisthobranchia) and the ecological associations with their food plants. Evol Ecol 11(3):301-335

Jensen KR (2007) Biogeography of the Sacoglossa (Mollusca, Opisthobranchia). Bonn Zool Beitr 55(3/4):255-281

Jensen K (2011) Comparative morphology of the mantle cavity organs of shelled Sacoglossa, with a discussion of relationships with other Heterobranchia. Thalassas 2:169-192

Jensen K (2015) Sacoglossa (Mollusca: Gastropoda: Heterobranchia) from northern coasts of Singapore. Raffles Bull Zool Suppl 31: 226-249

Jensen KR, Ong RSL (2018) A fold in the visor: formation of the bivalved shell in Berthelinia singaporensis Jensen, 2015 (Gastropoda: Heterobranchia: Sacoglossa), with notes on spawning and development. Raffles Bull Zool 66:797-809

Kawaguti S (1959) Formation of the bivalve shell in a gastropod, Tamanovalva limax. Proc Jpn Acad 35(10):607-611

Kawaguti S, Baba K (1959) A preliminary note on a two-valved sacoglossan gastropod, Tamanovalva limax, n. gen., n. sp., from Tamano, Japan. Biol J Okayama Univ 5:177-184

Kawaguti S, Yamasu T (1960) Spawning habits of a bivalved gastropod, Tamanovalva limax. Biol J Okayama Univ 6:133-149

Kawaguti S, Yamasu T (1966) Feeding and spawning habits of a bivalved gastropod, Julia japonica. Biol J Okayama Univ 12:1-9

Kay A (1962) Julia exquisita Gould, a bivalved gastropod. Pac Sci 16:434-435

Krug PJ, Vendetti JE, Rodriguez AK, Retana JN, Hirano YM, Trowbridge CD (2013) Integrative species delimitation in photosynthetic sea slugs reveals twenty candidate species in three nominal taxa studied for drug discovery, plastid symbiosis or biological control. Mol Phylogenet Evol 69:1101-1119
Krug PJ, Vendetti JE, Ellingson RA, Trowbridge CD, Hirano YM, Trathen DY, Rodriguez AK, Swennen C, Wilson NG, Valdés AA (2015) Species selection favors life histories in sea slugs, but higher per-offspring investment drives shifts to short-lived larvae. Syst Biol 64:983-999.

Krug PJ, Wong NLWS, Medina M, Gosliner TM, Valdés ÁA (2018) Cryptic speciation yields remarkable mimics: a new genus of sea slugs that masquerade as toxic algae (Caulerpa spp.). Zool Scr 47:699-713

Kuroda T, Habe T (1951) Nomenclatorial notes. In: Kuroda T (ed) Illustrated Catalogue of Japanese Shells 1(13). Kairui-BunkenKankokai, Kyoto.

McCarthy JB (2017) Studies of phylogenetics, systematics, and morphology in two groups of Sacoglossa (Gastropoda: Panpulmonata). Unpublished MSc dissertation, California State Polytechnic University, Pomona

Meyer KD, Paul VJ (1992) Intraplant variation in secondary metabolite concentration in three species of Caulerpa (Chlorophyta: Caulerpales) and its effects on herbivorous fishes. Mar Ecol Prog Ser 82:249-257

Middelfart PU, Kirkendale LA, Wilson NG (2016) Australian tropical marine micromolluscs: an overwhelming bias. Diversity 8(3):17

Muta Harah Z, Japar Sidik B, Natrah FMI, Emmclan LSH, Wan Hazma WN, Nordiah B (2014) Seaweed community of the Merambong shoal, Sungai Pulai estuary, Johore. Malay Nat J 66:132-148

Pabst EA, Kocot K (2018) Phylogenomics confirms monophyly of Nudipleura (Gastropoda: Heterobranchia). J Molluscan Stud 84: 259-265

Phang SM, Yeong HY, Ganzon-Fortes ET, Lewmanomont K, Prathep A, Gerung GS, Tan KS (2016) Marine algae of the South China Sea bordered by Indonesia, Malaysia, Philippines, Singapore, Thailand and Vietnam. Raffles Bull Zool 34:13-59

Pojeta J Jr, Runnegar B, Morris NJ, Newell ND (1972) Rostroconchia: a new class of bivalved mollusks. Science 177:264-267

Runnegar B, Pojeta J Jr (1985) Origin and diversification of the Mollusca. In: Trueman ER et al (eds) The Mollusca, volume 10. Evolution. Academic, Orlando, pp 1-57

Sarma ALN (1975) Three new species of the bivalved gastropods Julia and Berthelinia found in Eastern Indian Ocean. Venus 34(1-2):11-25

Schrödl M (2014) Time to say "bye-bye Pulmonata". Spixiana 37:161164

Sigwart JD (2017) Molluscs all beneath the sun, one shell, two shells, more, or none. Curr Biol 27(14):R708-R710

Sigwart JD, Garbett A (2018) Biodiversity assessment, DNA barcoding, and the minority majority. Integr Comp Biol 58(6):1146-1156

Sigwart JD, Lindberg DR (2014) Consensus and confusion in molluscan trees: evaluating morphological and molecular phylogenies. Syst Biol 64(3):384-395

Sigwart JD, McLean L (2017) Contribution of Caulerpa spp. to marine mollusc species richness in the megadiverse Philippines. Visaya 5: $67-73$

Stevens GC (1989) The latitudinal gradient in geographical range: how so many species coexist in the tropics. Am Nat 133:240-256

Wägele H, Martin WF (2014) Endosymbioses in sacoglossan seaslugs: plastid-bearing animals that keep photosynthetic organelles without borrowing genes. In: Löffelhardt W (ed) Endosymbiosis. Springer, Vienna, pp 291-324

Wallace AR (1855) On the law which has regulated the introduction of new species. Ann Mag Nat Hist, 2nd Series 16:184-196

Wisely B (1962) An outline of the development of the bivalve gastropod, Midorigai australis Burn, 1960. J Malac Soc Aust (6):37-39

Publisher's note Springer Nature remains neutral with regard to jurisdictional claims in published maps and institutional affiliations. 